\title{
Soil Aquifer Treatment for Additional Upgrading Wastewater Effluent
}

\author{
Mahmoud A Elsheikh*, Mohammed E Basyony**, Mohammed R Ghazy** \& Rania M \\ Ibrahim** \\ *Civil Engineering Department, Menoufia University, ShebinElkom, Egypt \\ ${ }^{* *}$ Civil Engineering Department, Benha University, Benha, Egypt
}

\begin{abstract}
Soil Aquifer Treatment (SAT) systemscan be used for upgrading partially treated wastewater by allowing it to infiltrate into the soil for tertiary treatment and storage of water to meet the growing demand of wastewater reuse. In this study, a pilot plant of three soil columns of $2 \mathrm{~m}$ hight and $25 \mathrm{~cm}$ diametrwere designed and fabricated to study the quality improvement of the conventional effluent treated wastewater using three types of soil (fine, medium and coarse sand). The pilot was operated under three operational phases, The first phase was worked as 4 days wetting followed by 3 days drying cycle for a period of 6 months, the second phase was worked as 3 days wetting followed by 4 days drying for a period of two months. Meanwhile the third phase worked as 5 days wetting and 2 days drying for two months. The pilot plant of columns was feeding using the effluent of Qahasecondary wastewater treatment plant.

The results indicated that, the medium sandy soil operating with 3 days wetting/4 days drying cycles had the highest removal performance for BOD, COD and TSS (64\%, $38 \%$ and $86 \%)$ respectively. Fine, medium and Coarse soils can be operated under both 3 days wetting/4 days drying cycles and 5 days wetting/2 days drying cycles to meet the nitrification requirements of SAT under the Egyptian conditions.
\end{abstract}

\section{تحسين نوعية المياه الخارجة من محطات الصرف الصحي عن طريق المعالجة الاضافية داخل التربة}

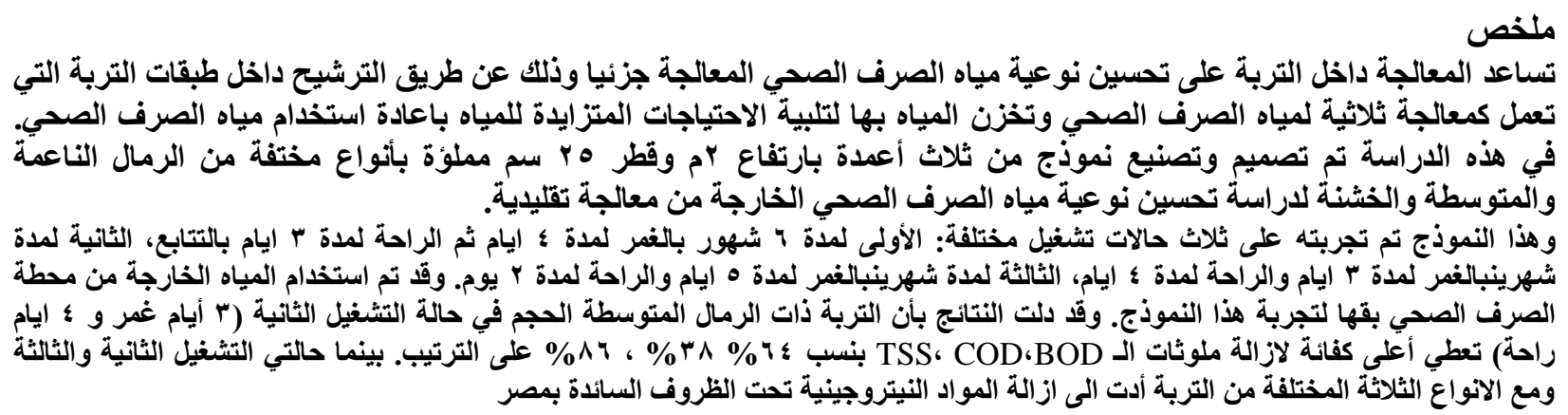

Keywords: Soil Aquifer Treatment (SAT); Soil aquifer, Tertiary Treatment, Sewage Treatment.

\section{Introduction}

The growing competition for water around the world are leading to even greater use of the enormous water resource. As part of this trend, there has been increasable interest in the use of treated wastewater as a water resource, especially in the countries water-short resources. Stated simply, Soil Aquifer Treatment (SAT) is a process by which excess surface water is directed into the ground (either by spreading on the surface, by using recharge wells, or by altering natural conditions to increase infiltration) to replenish an aquifer.

The impaired SAT waters quality is one of many strategies that can be used, alone or in conjunction with other strategies, to increase water supplies, such as reducing water consumption, reuse of treated 
wastewater or creating secondary water systems that deliver certain wastewaters directly to nonpotable uses. Aquifer recharge for the wastewater reuse has been considered and studied as a promising process to cope with the worldwide water scarcity [Elsheik\&Elhamidy 2012, 21014].

SAT reclaimed water provides one of the possibilities of a supplement of groundwater with additional advantages as follows: reduction of groundwater levels decline, protection of underground freshwater in coastal aquifers against intrusion from the ocean, and storage of reclaimed water for future reuse [Miller 2006].

SAT has been found to be a low cost sustainable tertiary wastewater treatment technology, which has the ability to generate high quality effluent from secondary treated wastewater for potable and non-potable uses [Cha et al. 2006,Essandoh et al. 2006].

The soil aquifer treatment technology may be an effective tool can be applied in Egypt for improving the quality of treated effluent sewage for the safety and non-restricted irrigation use compared with the direct currently common use. Through the aquifer soil, advanced sewage treatment stage was been added by which most of the biological load will be removed and reduction in concentrations of some chemicals can be found.

\section{Materials and methods}

\section{Soil Aquifer Treatment Simulation}

These experiments were performed using a pilot plant consisting of three parallel columns reactors, each column were constructed with a plastic tube (inner diameter of $25 \mathrm{~cm}$ and wall thickness of $0.5 \mathrm{~cm}$ ). Column was equipped with 8 ports at equal heights ( 25 $\mathrm{cm}), 1$ constant head overflow weir were located at depths of $25 \mathrm{~cm}$ from the top of the columns and used to maintain the desired constant head at the top of the soil, and 1 column outlet at the bottom. Sampling ports were installed at depths of 50,100 and $150 \mathrm{~cm}$ from the top of the Soil and used for the collection of water samples, About $20 \mathrm{~cm}$ of headspace above the top soil was provided to pond the wastewater effluent during the flooding. Gravel support is at the bottom of the columnof $10 \mathrm{~cm}$ depth as shown in "Figure 1".

Each column was filled with a kind of sand soil (coarse, medium, fine). Table 1 summarizes the characteristics of the columns soil. The columns were used to simulate a SAT system by employing three phases of cyclic operations.
Table 1. Characteristics of the column soils

\begin{tabular}{|l|c|c|c|}
\hline Variables & $\begin{array}{c}\text { Column } \\
\text { A }\end{array}$ & $\begin{array}{c}\text { Column } \\
\text { B }\end{array}$ & $\begin{array}{c}\text { Column } \\
\text { C }\end{array}$ \\
\hline $\begin{array}{l}\text { Soil } \\
\text { classification }\end{array}$ & $\begin{array}{c}\text { Coarse } \\
\text { Sand }\end{array}$ & $\begin{array}{c}\text { Medium } \\
\text { Sand }\end{array}$ & $\begin{array}{c}\text { Fine } \\
\text { Sand }\end{array}$ \\
\hline $\begin{array}{l}\text { Dry bulk } \\
\text { density }\left(\mathrm{g} / \mathrm{cm}^{3}\right)\end{array}$ & 1.54 & 1.56 & 1.53 \\
\hline $\begin{array}{l}\text { Effective Size } \\
(\mathrm{mm})\end{array}$ & 0.425 & 0.3 & 0.25 \\
\hline $\begin{array}{l}\text { Coefficient of } \\
\text { Uniformity }\end{array}$ & 3.6 & 2.5 & 6 \\
\hline
\end{tabular}

Wastewater effluent and characteristics

Wastewater effluents were collected from QAHA wastewater treatment plant, El-Qulibya, Egypt. It receives sewage from Qaha city and it's located at Qaha - Elqanater Road. Thus the secondary effluent from the plant, where wastewater is treated by an oxidation ditch process, was used in this study as a feed for the SAT-simulated soil columns. The quality of the influent and the effluent of the Qaha Wastewater Treatment Plant during the study period is summarized in Table 2.

\section{Pilot Operation}

The pilot plantwas started work from December 2013 till September 2014 (Ten Months) to cover the yearly climate change according to Egyption conditions and operated under three operational schedules: Phase 1 of 4 days wetting followed by 3 days drying cycle for a period of 6 months, Phase 2 of 3 days wetting followed by 4 days drying for a period of 2 months and Phase 3 of 5 days wetting and 2 days drying for 2 months using the secondary treated wastewater produced from QAHA treatment plant. The flow rate of wastewater that flow into the media was measured. The influent sample were obtained from the tank and analyzed at the same time of day to avoid change in the characteristics of the wastewater. Nine other samples (three samples for each column) at $1.5,1$ and $0.5 \mathrm{~m}$ soil depth were taken from the effluentthe three columns (after wetting days) then the system was turned to the drying cicledays .This procedure was repeated for the ten months.

Table 2.The quality of the influent and the effluent of the Qaha Wastewater Treatment Plant during year 2014

\begin{tabular}{|c|c|c|c|c|c|c|c|c|c|}
\hline \multirow{2}{*}{ Parameter } & \multirow{2}{*}{ Unit } & \multicolumn{4}{|c|}{ Influent } & \multicolumn{5}{c|}{ Effluent } \\
\cline { 3 - 10 } & & Av & Min & Max & S.D & Av & Min & Max & S.D \\
\hline TSS & $\mathrm{mg} / 1$ & 230 & 213 & 312 & 13 & 17 & 8 & 43 & 2.84 \\
\hline VSS & $\mathrm{mg} / 1$ & 166 & 151 & 245 & 8.93 & 14 & 7 & 37 & 1.40 \\
\hline TDS & $\mathrm{mg} / 1$ & 774 & 723 & 795 & 31 & 692 & 666 & 726 & 23.8 \\
\hline BOD & $\mathrm{mg} / 1$ & 524 & 460 & 550 & 36 & 18 & 10 & 42 & 8 \\
\hline COD & $\mathrm{mg} / 1$ & 777 & 725 & 805 & 33 & 49 & 22 & 77 & 7 \\
\hline $\begin{array}{c}\text { Oil\& } \\
\text { Grease }\end{array}$ & $\mathrm{mg} / 1$ & 29 & 23 & 41 & 7.15 & 3 & 1 & 5 & 1.67 \\
\hline PH & value & 7.17 & 6.93 & 7.56 & 0.22 & 7.41 & 7.23 & 7.62 & 0.11 \\
\hline Temp & ${ }^{\circ} \mathrm{C}$ & 26 & 20 & 30 & 1.61 & 27 & 21 & 31 & 1.46 \\
\hline
\end{tabular}




\section{Analytical Measurements}

The samples of wastewater and their charachteristics are chemically and physically analyzed in different laboratories. Biochemical oxygen demand (BOD), chemical oxygen demand (COD), total Suspended Solid TSS, PH and Temperature were analyzed in thelaboratory of QAHA treatment plant. While Ammonia NH3, nitrate NO3 and Phosphate P were analyzed in the Sanitary Engineering Lab in Benha faculty of Engineering, Benha and National Research Center, Cairo, Egypt. All the above mentioned parameters were analyzed according to the standard methods for examination water and wastewater $22^{\text {nd }}$ edition 2005.

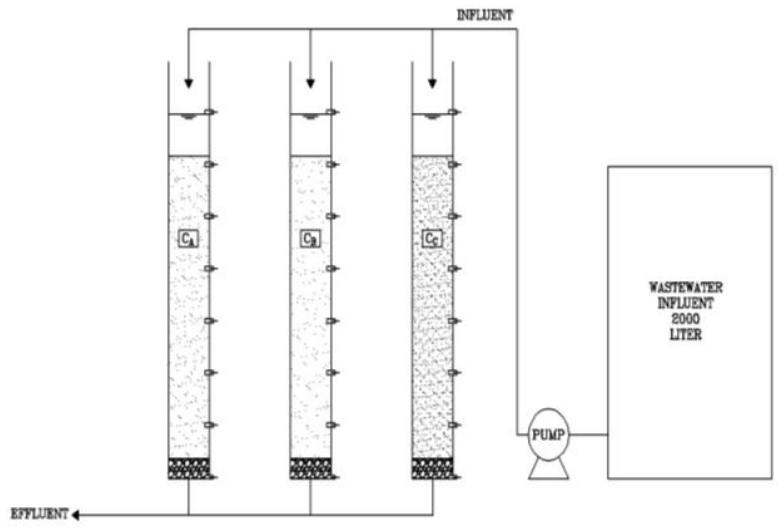

Figure 1. A schematic diagram of the SAT pilot plant system set-up used in this study.

Percent removal efficiencies of the measured parameters were calculated from

$\mathrm{Re} \%=(1-\mathrm{C} / \mathrm{Co}) \mathrm{X} 100$

Where $\mathrm{Re}$ is percent removal efficiency (\%), $\mathrm{C}$ is effluent concentration $(\mathrm{mg} / \mathrm{l})$, and $\mathrm{Co}$ is influent concentration $(\mathrm{mg} / \mathrm{l})$.

\section{Results and discussion}

\section{BODand COD Removal}

Wastewater contains a variety of natural and synthetic organic compounds, usually not individually identified, but collectively expressed in terms of the biochemical oxygen demand $\left(\mathrm{BOD}_{5}\right)$, and the chemical oxygen demand (COD. The soil with its biomass is extremely versatile and effective in decomposing natural and synthetic organic compounds that enter the soil with the wastewater. This decomposition tends to proceed more rapidly and completely under aerobic than anaerobic conditions. The fate of organic compounds in soil is normally not evaluated for each compound, but for the organic compounds collectively, as expressed by $\mathrm{BOD}_{5}$ and COD.

Figure 2 shows the average BOD removal through the fine, medium and coarse sandy soil at differentoperation. The influent BOD ranged between 42 and $10 \mathrm{mg} / \mathrm{L}$ and. The influent wastewater quality refers to quality of Qaha wastewater plant. The result indicated that, the medium sandy soil is the most affected soil with maximum removal efficiency $(\mathrm{Re} \%=$ $64 \%$ ) is obtained at Phase II operation cycle (3 days wetting / 4 days drying) at a flow rate $0.158 \mathrm{~L} / \mathrm{min}$.

The study of A.Akber, et al (2003) indicate that the BOD removal efficiency was $90 \%$ when using Muddy Sand and Gravelly Muddy sand. Madhavi, et al (2012) find that the clay is suitable for removing BOD \& COD under frequent wetting and drying cycles.

Figures 3 shows COD removal during different operation cycles. The influent COD varied between 77 and $22 \mathrm{mg} / 1$, whereas the average value effluent varied between 29 and $19 \mathrm{mg} / \mathrm{l}$, for all types of soils , COD removal is not as good as BOD. This might be due to the presence of refractory organics in wastewater.

Medium sand soil is considered the most affected soil for removing COD in the phase 2 by efficiency $38 \%$.

The study of A.Akber, et al (2003) indicate that the COD removal efficiency was $99 \%$ when using Muddy Sand and Gravelly Muddy sand. During SAT, the saturated (wet cycle) and unsaturated (dry cycle)zones of the natural soil and groundwater aquifer act as the medium in which physicochemical and biological reactions occur [Cha, et al. 2006]. These reactions substantially reduce the levels of organic and inorganic compounds leading to an improvement in water quality [Fox \&Makam, 2009]. Mixing of the infiltrated wastewater with the groundwater and the slow movement through the aquifer increases the contact time with the aquifer material leading to further purification of the water [Asano \&Cotruvo. 2004,Dillon, et al. 2006]. Redox conditions and residence time can have a significant influence on the kinetics of dissolved organic carbon (DOC) degradation and may affect its removal efficiency[Grunheid, et al. 2005].

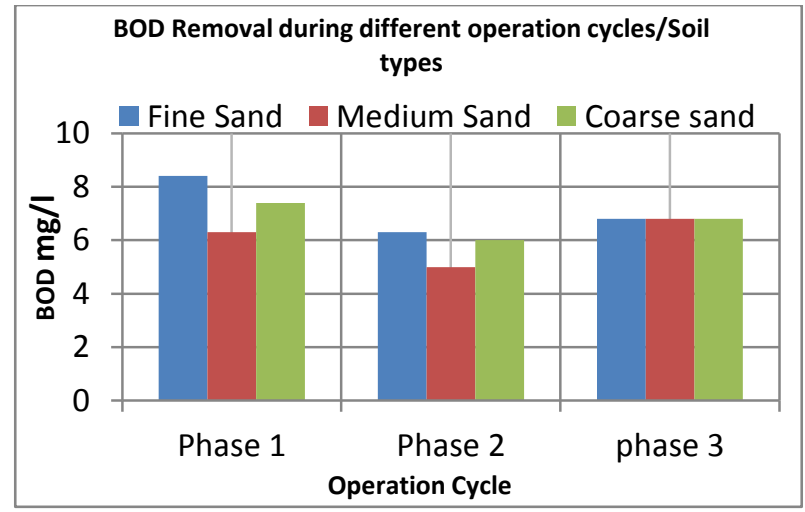

Figure 2. BOD Removal during different operation cycles/Soil types 


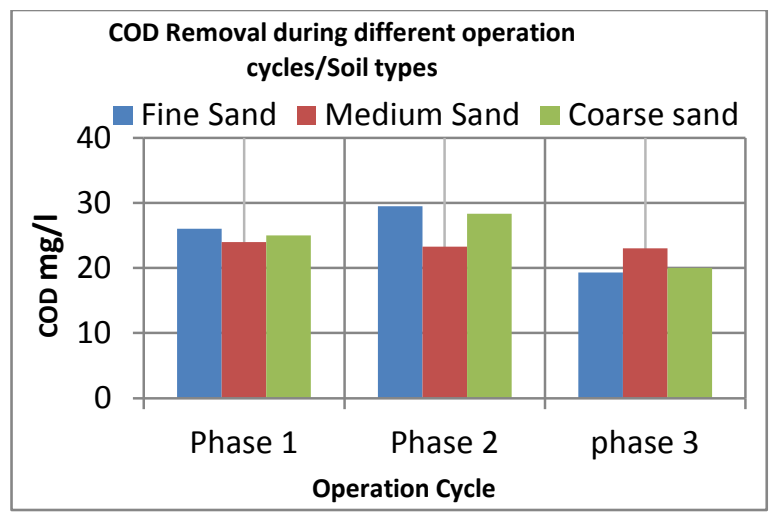

Figure 3.COD Removal during different operation cycles/Soil types

\section{TSS Removal}

Total suspended solids (TSS) are usually rather fine and mainly in organic form (sewage sludge, bacteria, fibrous materials, algae cells, etc.). The soil, however, is a very effective filter, and suspended solids should be essentially completely removed from the wastewater after about $1 \mathrm{~m}$ of percolation (M. Al-Senaft, et. Al 2005). The TSS at the inlet varied between 43 and $8 \mathrm{mg} / \mathrm{l}$. After the application of SAT, the TSS dropped to $1 \mathrm{mg} / \mathrm{l}$ in the three phases. The Highest Re\% of TSS was obtained in the case of the medium sandy soil with value $86 \%$ at phase 2 operation cycle.Reductions of microbial in infiltrate wastewater were demonstrated using survival experiments. The reductions in microbial pathogens were attributed to a combination of physical removal processes and the activity of indigenous microorganisms [Toze\&Bekele 2009].

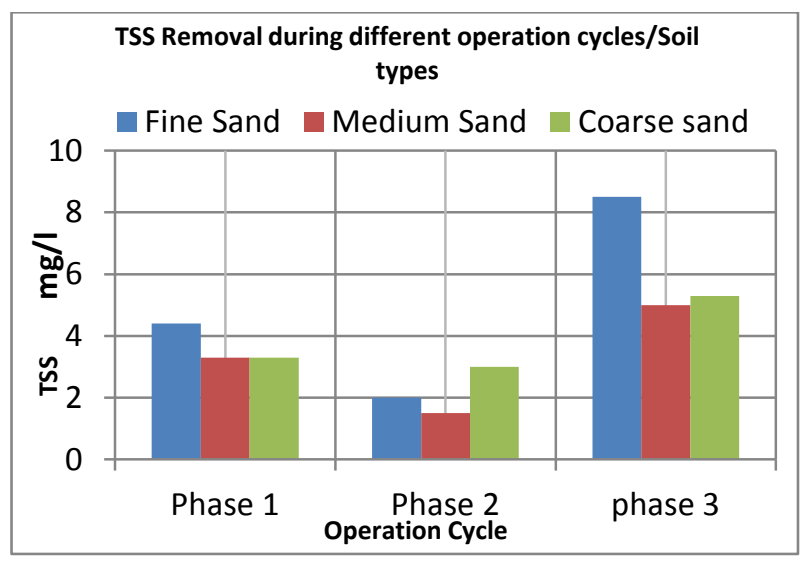

Figure 4. TSS Removal during different operation cycles/Soil types

A major operational feature of infiltration systems for treatedwatsewater is soil clogging caused by accumulation of suspended solids and strained out on the soil surface. The suspended solids can be inorganic, organic or grown biofilms. Their thickness may range from $1 \mathrm{~mm}$ or less to $0.3 \mathrm{~m}$ or more [Bouwer, 2002].
On the other hand, the controlled soil clogging accompanied with bioprocesses improves water quality. Considering both positive and negative influence of pollutant removal, biological clogging in porous media must be depicted by examining a correlation between bacterial growth and hydraulic conductivity [Page et al. 2011].

Three different clogging mechanisms were suggested depending on the flow rate and substrate concentration: (1) clogging at a high flow rate can be accelerated and easily eliminated by high shear force, (2) clogging at a low flow rate of local biofilm growths can be sloughed, and (3) clogging in a solution with high substrate concentrations cannot be easily eliminated because of the growth of dense biofilms [Kim et al. 2010].

\section{Ammonia \& Nitrate Removal}

The nitrogen removal processes in a biological filter mainly involves several ecological processes, including ammonification, aerobic ammonium oxidation, nitrite oxidation, anaerobic denitrification, heterotrophic nitrification, aerobic denitrification, anaerobic ammonium oxidation, biological nitrogen fixation, dissimulator nitrate reduction, and Achaea ammonium oxidation ( $\mathrm{Ji}$ et al. 2013, Satoh \&Rulin 2004). According to previous research, nitrification and denitrification are the main mechanisms that are responsible for eliminating nitrogen from sewage water (Dong \& Sun 2007; Wang et al. 2010). Kopchynski et al. (1996) studied the effects of soil type and effluent pretreatment on soil aquifer treatment. In this study, ten $2.6 \mathrm{~m}$ columns were operated under different flooding and drying cycles. The results indicate that effluent pretreatment has a complete removal of ammonia.

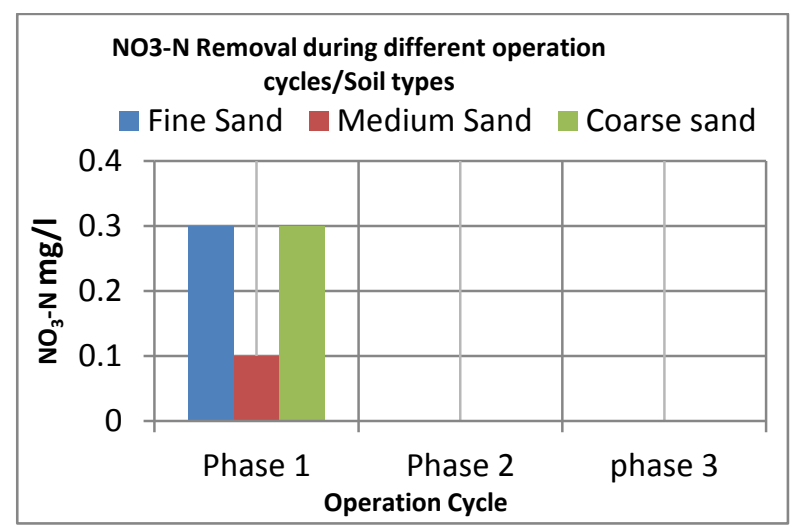

Figure 5. Nitrate Removal during different operation cycles/Soil types 


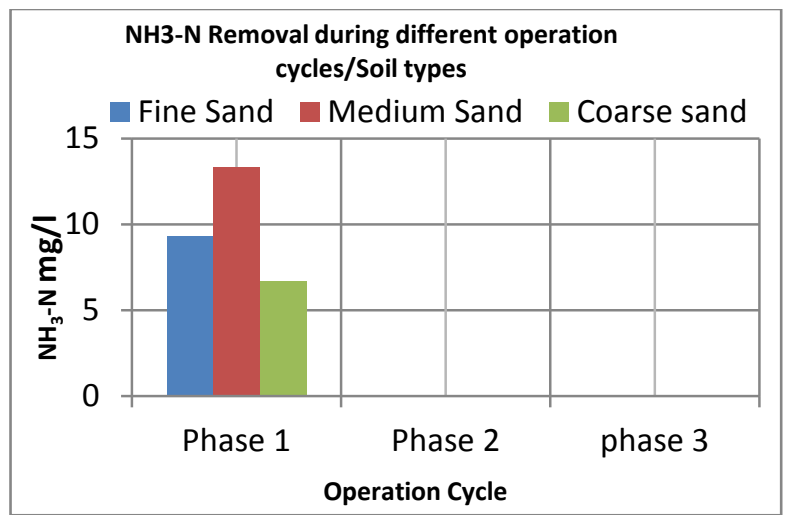

Figure 6. Ammonia Removal during different operation cycles/Soil types

In this experiment, For the first phase, the behavior of nitrate $\mathrm{NO}_{3}-\mathrm{N}$ and Ammonia $\mathrm{NH}_{3}-\mathrm{N}$ are decrease according to the stability of SAT system. Figure 5 shows the removal in Nitrate through soil column, its value was varied between 4.9 and $0.1 \mathrm{mg} / \mathrm{l}$ in the inlet for phase $1,1.5$ and $0.4 \mathrm{mg} / \mathrm{l}$ for phase 2 and varied between 1.6 to $0.2 \mathrm{mg} / \mathrm{l}$ for phase 3 . The effluent of Nitrate is decrease to zero value in all soil columns at $1.5 \mathrm{~m}$ soil depth.

Figure 6 shows the removal in ammonia through fine, medium and coarse sand soil. The level of ammonia in the inlet varied between 27.2 and $1.1 \mathrm{mg} / \mathrm{l}$ for phase 1 , 25.7 and $13.5 \mathrm{mg} / \mathrm{l}$ for phase 2 and varied between 18.2 to $12.3 \mathrm{mg} / \mathrm{l}$ for phase 3 . The effluent of ammonia is decrease to zero value in all soil columns, indicating the complete conversion of ammonia to nitrate. This indicates a high aerobic environment within the subsurface zone.

Highest Re\% of ammonia and nitrate were obtained at Phase 2 operation cycle (3 days wetting / 4 days drying) for all types of soil with value $100 \%$.

The unsaturated zone (during dry cycle) has available oxygen due to ability of air flow in its porous during the drying period of the SAT treatment cycle. Availability of oxygen in the unsaturated zone is highly important in promoting aerobic biodegradation processes and nitrification. Factors influencing the efficiency of SAT include characteristics of treatment site, soil and wastewater characteristics, climate and infiltration rate [Tanik\&Comakoglu 1996].

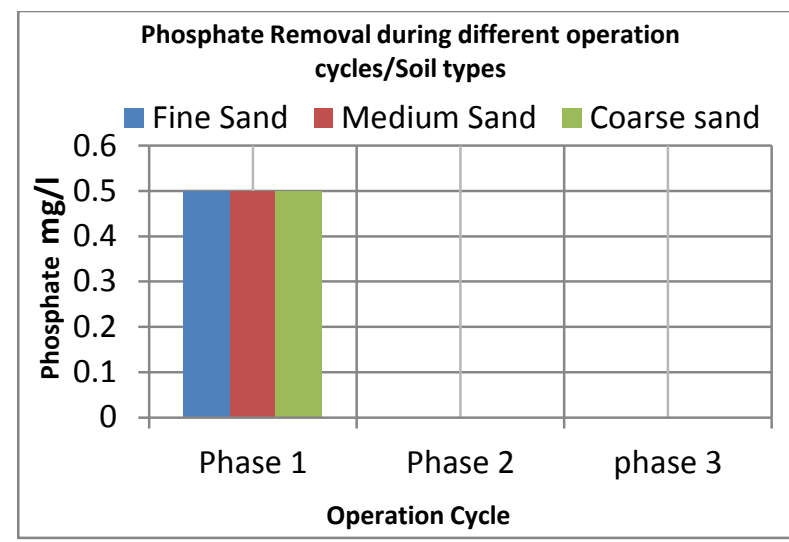

Figure 7. Phosphate Removal during different operation cycles/Soil types

\section{Phosphate Removal}

The phosphate concentration within the effluent from Qaha wastewater treatment plant was $1.1 \mathrm{mg} / \mathrm{l}$ on average. It decreases in all soils at three phases till zero value. Its known that phosphate is removed either through its adsorption by phosphate-fixing materials, such as iron oxide and aluminum oxide, or through a precipitating reaction with the calcium and magnesium ions presented in soil (Bouwer2002). Therefore, the phosphate removal in this study indicates that the phosphate removal is depending on characteristics of the soil column.

Adsorption and precipitation are reported to be the main causes of phosphorous retention in calcareous sands and soils [Wandruszka, 2006].

\section{Conclusion}

Soil column studies were carried out to evaluate the potential of SAT system in treating wastewater under varied experimental condition viz. soil type, depth of soil, initial concentration of pollutants and $\mathrm{pH}$. Based on the analysis of results the following conclusions have been drawn.

- The best removal efficiency occurs at $1.5 \mathrm{~m}$ soil.

- SAT system with medium sandy soil was more efficient in treating wastewater compared to fine and coarse sand.

- Medium sand is the better soil for reducing BOD, COD and TSS under phase II operation cycle (3wetting / 4drying).

- Soil column experiments showed that nitrification can remove up to $90 \%$ of ammonium nitrogen within a column of $1.5 \mathrm{~m}$ depth and also denitrification can be achieved during soil passage.

- Phosphate removal was generally very high.

\section{Acknowledgements}

Special grateful appreciation is expressed to Egyptian Academy of Scientific Research and Technology for 
funding this work.

I would like to thank the staff of water pollution control, National Research Center, and the staff of Qaha wastewater treatment plant for their help, guidance and providing the necessary laboratory results.

\section{References}

[1] Akber, A.; E.Al-Awadi and T.Rashid“Assessment of the use of soil aquifer treatment technology in improving the quality of tertiary treated wastewater in Kuwait", Emirates J. for Eng. Research, 8(2), 25-31, 2003.

[2] Dong, Z.Q., Sun, T.H.“A potential new process for improving nitrogenremoval in constructed wetlands-promoting coexistence of partialnitrification and ANAMMOX". Ecol. Eng. 31, 6978, 2007.

[3] Ji, G.D., He, C.G., Tan, Y.F.2013. "The spatial distribution of nitrogen removalfunctional genes in multimedia biofilters for sewage treatment. "Ecol. Eng. 55, 35-42, 2013.

[4] Kopchynski, T. Fox, P.Alsamadi, B. and Berner, M. "The Effects of Soil type and effluent pretreatment on soil aquifer treatment," Water Reasearch technology 34(11). 235-242, 1996

[5] Madhavi, G, V.R Raji and S. Lavanya"Aquifer Recharge with reclaimed water through soil aquifer treatment,India water week 2012- water, energy and food security , 10-14, 2012"

[6] M. Al-Senafy, M. Viswanathan, T. Rashid and K. Al-Fahad, "Efficiency of the SAT Technique in Improving the Quality of the Wastewater," in Emirates Jof Eng.Reasraech, 10 (1), 79-88, May 2005.

[7] Satoh, H., Rulin, B. "Macroscale and microscale analyses of nitrificationand denitrification in biofilms attached on membrane aerated biofilm reactors. "Water 483 Res. 38, 1633-1641,2004.

[8] Wang, X., Sun, T., Li, H., Li, Y., Pan, J."Nitrogen removal enhanced byshunt distributing wastewater in a subsurface wastewater infiltration system. "Ecol. Eng. 36, 1433-1438,2010.

[9] Elsheik, M A\&W K Elhamidy. 2012. Wastewater Reuse Through Soil Aquifer Treatment. International Conference on Environment (ICENV 2012), 11-13 Dec. 2012, Penang, Malaysia.

[10]Elsheik, M A \& W K Elhamidy.2014. Pollution Control of Wastewater in Recharge Aquifer. 2nd Int. Conf. on Advances in Eng. - CSM 2014. Birmingham, UK, 16-17, Nov. 2014
[11]Essandoh, H. M. K.; C. Tizaoui, M.H.A. Mohamed, G. Amy, D. Brdjanovic. 2011. Soil aquifer treatment of artificial wastewater under saturated conditions. Water Research 45 (2011) 4211- 4226.

[12] Miller, G. W. 2006. Integrated concepts in water reuse: managing global water needs. Desalination $187,65-75$.

[13] Cha, W.; Kim, J., Choi, H., 2006. Evaluation of steel slag for organic and inorganic removals in soil aquifer treatment. Water Research 40 (5), 1034-1042.

[14]Fox, P.; R. Makam, 2009. Surface area and travel time relationships in aquifer treatment systems. Water Environment Research 81 (11), 2337-2343.

[15] Asano, T.; J. A Cotruvo. 2004. Groundwater recharge with reclaimed municipal wastewater: health and regulatory considerations. Water Research, Volume 38, Issue 8, April 2004, 19411951

[16] Dillon, P.; Pavelic, P., Toze, S., Rinck-Pfeiffer, S., Martin, R., Knapton, A., Pidsley, D., 2006. Role of aquifer storage in water reuse. Desalination 188 (13), 123-134.

[17] Tanik, A.; Comakoglu, B., 1996. Nutrient removal from domestic wastewater by rapid infiltration system.J. of Arid Environ. 34 (3), 379-390.

[18] Grunheid, S.; Amy, G., Jekel, M., 2005. Removal of bulk dissolved organic carbon (DOC) and trace organic compounds by bank filtration and artificial recharge. Water Research 39 (14), 3219-3228.

[19] Wandruszka, R. von 2006. Phosphorus retention in calcareous soils and the effect of organic matter on its mobility.Geochemical Transactions 7 (6).doi:10.1186/1467-4866-7-6.

[20] KimJ. W.; H. Choi, Y. A. Pachepsky. 2010. Biofilm morphology as related to the porous media clogging. Water Research 44 (2010) 1193-1201.

[21]Bouwer,H. 2002. Artificial recharge of groundwater: hydrogeology and engineering. Hydrogeology J. 10 (1), 121-142.

[22] Toze, S.;Bekele, E., 2009. Determining Requirements for Managed Aquifer Recharge in Western Australia.A Report to the Water Foundation. CSIRO, Canberra, AU. 2009.

[23] Page,D.; K. Miotli-nski, P. Dillon, et al. 2011. Water quality requirements for sustaining aquifer storage and recovery operations in a low permeability fractured rock aquifer. J. of Environ. Manage. 92 (2011) 2410-2418. 